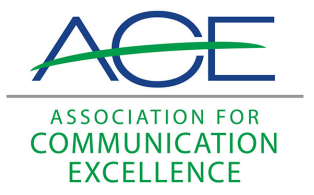

Journal of Applied Communications

\title{
Cultivating Identity, Sowing Relationships, Fertilizing Success, and Harvesting Coexistence: Understanding Oklahoma Producer Identity and Relationships
}

\author{
Audrey E. H. King \\ Oklahoma State University \\ Quisto Settle \\ Oklahoma State University
}

Follow this and additional works at: https://newprairiepress.org/jac

c) (†) (-)

This work is licensed under a Creative Commons Attribution-Noncommercial-Share Alike 4.0 License.

\section{Recommended Citation}

King, Audrey E. H. and Settle, Quisto (2021) "Cultivating Identity, Sowing Relationships, Fertilizing Success, and Harvesting Coexistence: Understanding Oklahoma Producer Identity and Relationships," Journal of Applied Communications: Vol. 105: Iss. 2. https://doi.org/10.4148/1051-0834.2369

This Research is brought to you for free and open access by New Prairie Press. It has been accepted for inclusion in Journal of Applied Communications by an authorized administrator of New Prairie Press. For more information, please contact cads@k-state.edu. 


\title{
Cultivating Identity, Sowing Relationships, Fertilizing Success, and Harvesting Coexistence: Understanding Oklahoma Producer Identity and Relationships
}

\author{
Abstract \\ The USDA has identified coexistence, or producers growing food in a variety of ways (conventionally, \\ organic, etc.) in a harmonious manner as a critical challenge and high priority. Despite this call for \\ coexistence and assurance of mutual success, agricultural sectors often have conflicts. Both sides of the \\ niche and mainstream rift tend to pick and choose radical examples of problematic practices to portray \\ the opposition. Producers, more so than most other occupations, have a deeply entrenched occupational \\ identity. Many studies focused on the need for relationships between agricultural producers and the \\ public. No work has been found to understand how producers from different sectors of agriculture view \\ one another. This study sought to understand producers' identities and the relationships producers have \\ with one another. Results indicate the occupation of farming, family ties, connection and duty to the land, \\ hard work and pride defines producers' identities. When defining a "good farmer," producers cited \\ innovation and efficiency, farm succession, passion and joy, and profits as markers of success. The \\ relationships between producers varied. Overall, producers respected other producers enough to make \\ their own choices concerning production. Social media was often mentioned when producers talked \\ about how they communicate with one another.
}

\section{Keywords}

qualitative interviews, social identity, producer relationships

\section{Cover Page Footnote/Acknowledgements}

This work was supported by the USDA National Institute of Food and Agriculture, Hatch project OKL03072. A version of this paper was presented at the 2020 American Association for Agricultural Education National Research Conference. 


\section{Introduction}

\section{Producer Identity}

Agricultural producers, more so than most other occupations, have a deeply entrenched occupational identity (Abrams et al., 2013). Some researchers even posit farming is not just an occupation but an ethnicity (Bell et al., 2004). Researchers have found producers' primary motivation in farming is not to make money, but to simply farm: "Farming is a vocation and a lifestyle, with profitability being a means to an end, not an end in itself, and farmers often have a strong emotional attachment to their land, livestock, and farming style" (Van Dijk et al., 2016, p. 181). This emotional attachment is exacerbated by family's influence on farmers and their identity. Producers have cited a family heritage in the industry as a point of pride and component of identity (Bell et al., 2004). Producers use "their family legacies and life experiences on the farm to inform their sense of who they are and what a farmer ought to be" (Arnold, 2017, p. 84). Farmers' identity is also influenced by the autonomy and freedom operating a family run business offers (Stock \& Forney, 2014). Autonomy may be an important element in describing the experience of being a farmer in the larger agricultural industry and farmers' preparedness to adopt new practices (Stock \& Forney, 2014).

If a producer commits to a type of practice or sector of the industry, it becomes part of their identity, which makes it difficult for producers to consider changing those commitments (Brandth \& Haugen, 2011; Gray \& Gibson, 2013). As agriculture is an ever-evolving industry, a producer's identity is often evolving. "The struggle to create a stable identity against the backdrop of uncertainty becomes an ongoing accomplishment that provides meaning to the lives of ... farmers" (Bell et al., 2004, p. 122). The identity of producers is complex, fluid, and influenced by multiple entities.

Producers strive to create an identity of being a good farmer (Phillips \& Gray, 1995). Definitions used by producers to constitute good farming vary. Producers used ideas of community participation, respectability, and farming ability as criterion to assess the quality of other producers (Phillips \& Gray, 1995). Perhaps the most prevalent idea of a good farmer in the United States is one of hyper productivity, input intensive, and ever-increasing yields, often referred to as a productivist (McGuire et al., 2012). Some consider being a conservationist as the definition of a good farmer. Others think a producer who farms conventionally, takes few risks, and remains consistent from year to year is the definition of a good producer. Still others consider those who are innovative, try new techniques, focus on sustainable production, and are progressive to be good producers (Phillips \& Gray, 1995). The occupation of farmer is essential to a farmer's identify, but the definition of what makes a good farmer is highly contested.

Recently producer identity has been studied to more fully understand the decision making process and adoption behaviors (Lequin et al., 2018; Sulemana \& James, 2014; Van Dijk et al., 2016; Warren et al., 2016). These studies have shown a producer's identity affects producer adoption decisions, specifically in relation to pro-environmental practices (Hyland et al., 2016; Lequin et al., 2018; Sulemana \& James, 2014; Van Dijk et al., 2016). Consequently, the selfconcept and identity of producers affect agricultural and land management decisions (Groth \& Curtis, 2017). In the case of farmers in New Zealand, identity was influenced by relationships, culture, social experiences, and financial rewards (Rosin, 2013). A study of Finnish agricultural producers found they identified themselves equally as entrepreneurs and farmers (Vesala \& Vesala, 2010). Researchers believe each producer has multiple social identities (Burton \& Wilson, 
2006; McGuire et al., 2015). Understanding a farmer's identity is essential because identity drives how one behaves (Stryker \& Burke, 2000).

\section{Producer Relationships}

Many studies have focused on the need for increased relationships between agricultural producers and the public (King, 2008; Sharp \& Smith, 2003). For instance, agro-ecological systems (e.g., community supported agriculture, farmers markets, and community gardens) have been cited as vehicles to foster community relationships and resilience (King, 2008). Older farmers can be particularly influential in farmer networks "because of their proclivity for engagement in community service and their large stocks of economic, social, and cultural capital" (Cole \& Donovan, 2008, p. 92). While social networks are important in rural communities, they are often underutilized (Bollman \& Reimer, 2009).

Moreover, attention has been paid to the failing relationships between producers and agricultural companies such as Monsanto (Kinchy, 2012). However, few studies have addressed relationships between producers. Previous research suggests there is rising competition between producers, and they are becoming less likely to turn to their neighbors for answers (Bell et al., 2004; Rotz, 2017). The regulations organic or niche producers must follow may restrict their neighbors' abilities to use herbicides, pesticides, or genetically altered seeds (Kinchy, 2012). This can create feelings of resentment and ill will between neighbors.

Networking is an important aspect of learning for organic growers and it has been cited as the most important source of information for niche producers (Crawford et al., 2015). Through networking, producers create social connections and gain social capital (Bennett, 1968). In 2013, Läpple found organic producers were most likely to rely on other organic producers for information, particularly while converting their operations to organic. Moreover, higher social integration of producers and information networks resulted in higher adoption of organic practices (Läpple, 2013). Producers often experiment with different crops or practices. Sharing the results of such experiments with friends, neighbors, or peers is a regular part of their lives (Gray \& Gibson, 2013). Online resources have been found to be less effective than other forms of communication, such as networking and university sources (Crawford et al., 2015).

\section{Value of Relationships in Rural America}

Mental health is a growing concern in rural America. Research has found mid-scale farmers are more pessimistic, anxious, and feel they have little control over their lives and livelihood when compared to others (James \& Hendrickson, 2010). There are also many concerns about suicide in rural America. There is a rural-urban divide in terms of suicide, with rural men especially being more prone to be victims of suicide (Singh \& Siahpush, 2002). The agricultural sector experiences high rates of suicide compared to other occupations (Milner et al., 2013; Tiesman et al., 2015). Lack of social ties was related to increased risk of suicide (Singh \& Siahpush, 2002). Research has also indicated social connections are linked to limiting injuries in farm work. Farmers are more likely to be injured than nonfarmers, particularly as farmers get older, but these risks are lower for farmers with good social support systems (Cole \& Donovan, 2008). 


\section{Coexistence}

Social connections are helpful for everyday existence and industry or system wide longevity. Coexistence between agricultural producers has been identified by the United States Department of Agriculture (USDA) as a critical challenge and priority for every agricultural producer. Coexistence is defined as "the concurrent cultivation of conventional, organic, identity preserved and genetically engineered crops consistent with underlying consumer preferences and farmer choices" (USDA, 2015, para 2). Coexistence is the production of food in multiple ways to meet domestic and global food needs. The increasing demands of consumers for nutritious and affordable food cannot be satisfied by any one sector of agriculture:

As one sector of agriculture expands, so does the entire agriculture industry. All farmers. . . should benefit from the continued growth of all. . sectors of U.S. agriculture, as should the local communities and food industries that support agriculture. (USDA, 2015, para. 5)

One manner coexistence can show itself is through coopetition, which is "the dyadic and paradoxical relationship that emerges when two firms cooperate in some activities, such as in a strategic alliance, and at the same time compete with each other" (Bengtsson \& Kock, 2000, p. 412). While competition may exist between producers to market their products to consumers, there may simultaneously be opportunities for cooperation to be fostered on the input side of production (Bengtsson \& Kock, 2000). A sense of a collective identity and belonging can help foster coopetition in a business community (Mathias et al., 2017; Said, 2019).

Despite this call for coexistence and assurance of mutual success, agricultural sectors often have conflicts with each other. If producers from all sectors of agriculture can foster social capital with each other, it may mitigate some conflict between groups. "Communities with high social capital enable individuals to feel accepted and respected as valuable members of that community, to make the most of the resources available to him or her, and in turn to reciprocate that affection and respect" (Cole, 2010, p. 80). Feelings of mutual respect and trust also help foster coopetition in a community (Kraus et al., 2019).

That said, social capital is collective in nature, so one producer acting nefariously could undo much of that social capital in a community of producers (Sharp \& Smith, 2003), which makes sense given both sides of the niche and mainstream agricultural rift tend to pick and choose radical examples of problematic practices to display (Tal, 2018). In 1990, Beus and Dunlap described the relationships between niche and mainstream producers as a "large chasm" and their practices as "fundamentally divergent" (p. 609). These tensions are exacerbated by declining rural communities, degraded environments, and conflicting ideas of the ideal producer (Gray \& Gibson, 2013). No work has been found to understand how producers from different sectors of agriculture view one another. 


\section{Theoretical Framework}

\section{Communication Theory of Identity}

According to the Communication Theory of Identity (CTI), there are four frames of identity: personal, enacted, relational, and communal (Hecht, 1993). One's personal identity is one's own self-image or concept. Only oneself is completely aware of one's personal identity. Enacted identity is the identity one presents or conveys to the world. Enacted identities are portrayed through communication. Relational identity is considered to be the way one considers themselves in relation to others, as well as identifying oneself through relationships (Jung \& Hecht, 2004). Lastly, the communal identity refers to the way a group of individuals define their identity as a collective. "The four frames of identity are not always consistent with each other. They can be contradictory or exclusive to each other. However. . . the frames still coexist and work together as part of identity" (Jung \& Hecht, 2004, p. 267). Producers' identities cannot be properly understood independent from the influence of personal history, relationships, social structure, and communities (Philips \& Gray, 1995).

The present study sought to understand producers' identities and the relationships producers have with one another. Fostering positive relationships between different types of producers could help to increase the resiliency of the agricultural industry and the communities it affects (USDA, 2015).

\section{Purpose and Research Questions}

The purpose of this study was to explore producers' descriptions of their identities in the agricultural community. The following research questions guided the study:

1. What are major components of how producers describe their identities?

2. How do producers define a "good farmer"?

3. How do producers relate to and share information with others involved in agriculture?

\section{Methods}

In order to answer the research questions, 13 semi-structured qualitative interviews were completed in Oklahoma in the summer of 2019. Qualitative research offers in-depth understanding of research topics (Creswell, 2012; Flick, 2009). Individual interviews were ideal as identity and relationships are inherently personal, and the open-ended questions in interviews offer participants the space to communicate their personal experiences comfortably (Creswell, 2012).

\section{Population}

Grain and oil crop, dairy, beef cattle, produce, nuts, and poultry producers were represented in the sample, all of which are common commodities in Oklahoma. Eight mainstream and five niche producers were interviewed. Producers who used conventional types of agricultural practices were considered mainstream. Producers were considered to be niche producers if they used alternative forms of agriculture such as organic or grass-fed methods or if they were agritourism operators. Producers were selected from different USDA crop reporting districts to ensure better representation of Oklahoma agriculture. Participants were recruited through a producer-member 
organization and through Facebook. The purposive sampling frame was used to interview producers who produced a variety of items with a variety of production practices in order to get a clear picture of producer perceptions. Producer type (i.e., mainstream or niche) was known at the time of recruitment and confirmed through data collection. Table 1 describes the study's participants.

\section{Table 1}

Study Participants

\begin{tabular}{llll}
\hline Pseudonym & Producer Type & \multicolumn{1}{c}{$\begin{array}{c}\text { Primary Operation } \\
\text { Type(s) }\end{array}$} & $\begin{array}{c}\text { Farming as Primary } \\
\text { Occupation }\end{array}$ \\
\hline Bill & Mainstream & Cow/calf & Yes \\
Bob & Mainstream & Cow/calf & No \\
Dave & Mainstream & $\begin{array}{l}\text { Wheat, soybean, corn, } \\
\text { cow/calf, stockers }\end{array}$ & Yes \\
Esther & Niche & Cattle, wheat & Yes \\
Gary & Niche & Garlic & Yes \\
Greg & Mainstream & Pecan, cow/calf & No \\
Joe & Mainstream & Cattle & Yes \\
Lionel & Mainstream & Cow/calf, wheat & Yes \\
Margaret & Niche & Dairy & Yes \\
Mike & Niche & Berries, vegetables, & No \\
& & agritourism & No \\
Susie & Mainstream & Wheat, cotton, canola, & soybeans, grain \\
Tammy & Niche & sorghum & Agritourism, cattle, hay \\
Tiffany & Niche & Agritourism, cattle, hay & No \\
Wayne & Mainstream & Chicken, cow/calf, hay & No \\
\hline
\end{tabular}

Note. Operation type are listed in the order in which participants mentioned them.

${ }^{a}$ Tammy and Tiffany were partners in their operation and interviewed together.

\section{Procedures}

The locations of interviews were at the discretion of the participants. These included kitchen tables, farm offices, and barns. The researcher-created questioning route was written to address the research questions using terms that were relatable and flowed logically from topic to topic. The guide helped maintain consistency from interview to interview, as recommended by Creswell (2012). The questioning route was reviewed by experts external from the author team for face validity (Creswell, 2012). The questions helped researchers gain an understanding of producers' identities, perceptions of other producers, and relationships with other producers. Questions were asked regarding producers' operations and history, production practices, challenges associated with their operations, short- and long-term goals, and definitions of success. Researchers also inquired about participants' neighbors and peers, and participants' perceptions of them, as well as their beliefs about society's perceptions of agriculture. The questions were general enough that the same interview guide was used for all producers. At the end of each interview, the 
researcher summarized the discussion and asked the participant to confirm its accuracy. This served as a member-check (Creswell, 2012). Interviews ranged from 45 to 90 minutes.

Internal consistency was addressed by comparing the interviewer's field notes with participants recorded and transcribed responses. The field notes were written on hardcopies of interview guides during each interview. Data were also collected from interviews via audio recorders. These combined data sources created an audit trail and are a record of the research from beginning to end (Flick, 2009). The audio recordings were transcribed by Temi, an online transcription application. Identifying information of participants was removed from transcripts and pseudonyms were assigned. The research protocol was reviewed by experts separate from the research team to ensure face and content validity (Cresswell, 2012). These experts included professors from agricultural communications and anthropology with research experience in producer behaviors and identity. Changes were made to improve the flow of questions and probing questions were added.

In order to ensure transcription was done correctly, the researcher listened to each interview from beginning to end. The software MAXQDA18 was used to code each transcript using Glaser's constant comparative method (1965). Codes are used in qualitative methods to label phrases used by participants to provide description and meaning (Creswell, 2012). Codes from transcripts were compared to codes from previous transcripts to create a comprehensive and inclusive system of codes (Glaser, 1965). Codes were grouped into categories, or sets of ideas or terms that mark division in a concept (DeSantis \& Ugarriza, 2000). Themes emerged from the data by grouping together categories that represented major ideas present, explained relationships between data categories, and explain phenomena within the data (Creswell, 2012; DeSantis \& Ugarriza, 2000; Glaser, 1965). "A theme is an abstract entity that brings meaning and identity to a recurrent experience .... a theme captures and unifies the nature or basis of the experience into a meaningful whole" (DeSantis \& Ugarriza, 2000, p. 362). Themes have form, unite and unify ideas, describe the underlying essence of an experience, and are woven throughout the data (DeSantis \& Ugarriza, 2000).

\section{Findings}

The major themes and supporting data that emerged from the 13 semi-structured interviews will be presented by research question. A description of participants can be found in Table 1 in methods.

\section{RQ 1: What Are Major Components of how Producers Describe Their Identities?}

To explore the major components of producers' identities, participants were asked to describe themselves, their operations, and the history of their operations. Interviews yielded the following themes: farmer identity is complex and multifaceted, and farmers' social self-conscious.

\section{Farmer Identity is Complex and Multifaceted}

The farmer identity is complex and multifaceted theme is defined as the interplay between the multiple components that make up a farmer's identity. In this theme, a farmer's identity is made up of components from their past and present experiences, and future aspirations. This theme traverses four categories of farmer identity: occupation, connection to family, duty to land, and work ethic. 
Occupation of Farming is a Major Component of Identity. Regardless of working onor off-farm, producers acknowledged farming as the main component of their identity. All participants in the study had been involved in agriculture in some fashion for their entire lives. Esther, a niche producer, said this about her husband and partner in farming: "He just said, 'You know what, this is who I am. This defines me. I love what I'm doing. I think there's a reason and a purpose for this ... . God had a plan for us." Bill, a mainstream producer, said "Being a cattleman is something I take pride in and defines who I am."

Connection to Family Contributes to Farming and Identity. Family ties gave producers purpose and helped to form their identities. All 13 producers interviewed for this study mentioned family in some capacity. Joe, a mainstream producer, said, "One of the main goals of our operation is to raise a family on the farm. To me, farm kids are more well-rounded and have more common sense ... they see life, they see death . . . it's not a video game." Wayne, a mainstream producer also spoke of the importance of passing the farm to the next generation, "Transitioning from one generation to the next is a priority for me. .. I hope to raise grandsons or granddaughters in this lifestyle."

Producers also spoke of past generations in addition to the next generation of farming. Producers were quick to mention if they were operating a centennial farm or the number of generations that had been raised on the farm. Esther, a niche producer, said, "My husband and I both inherited our Oklahoma centennial farms. So, we have quite a longevity and history of farming in our family." Mike, a niche producer, said "My great-great-granddad homesteaded this place in 1895 and ran stock on it ... . I'm just hoping if he's looking down on me or up at me that he approves of what I'm doing with the land."

Duty to Land. A duty to the land was another major component of producer identity. Producers of all kinds had a sense of attachment to their land. Dave, a mainstream producer, spoke of land and the importance of maintaining its integrity: "You want to make a good living and feel good about what you're doing. You want to be a good steward of the land because there's another generation coming up behind you." Mike, a niche producer, described it as, "I'm real attached to my land, which is weird. Well, it's not to me. It's weird to some people. There is a lot of heritage that goes into the land and it's mine." Lionel, a mainstream producer, also shared these sentiments: "It's [the land] important to me. I mean, it's just land, it's just, property and stuff, but you know, for now it still means something."

Work Ethic Defines Producers. Working hard was a cornerstone for producers when describing themselves and their agricultural peers. Gary, a niche producer, said of himself and peers, "When you get up at five o'clock in the morning, most of the time you don't stop until dark, and it's not five days a week. It's every day. So we have to be a little crazy." Susie, a mainstream producer, described it like this:

Agriculture to me would be somebody who works hard, probably harder than the average bear. Whether you're my seed salesman or whether you are me as a crop insurance agent or my husband as a farmer or me as a farmer, you know, we're gonna put the hours in. Probably more so than a lot of than other sectors of work.

Producers had a great sense of pride associated with their operations and industry. When speaking about the public perception of agriculture, Dave, a mainstream producer said, "This is a living for us, but it's also a living for them too. Without it, basically, they wouldn't have nothing." Lionel, a mainstream producer, said, 
We have the most valuable asset in the world. making food. If you stop everything in oil and gas, we can continue. Stop all food, take it all out, just lock the stores up. Yeah, who's going to live? It's life and death then.

Mike, a niche producer, said "Both the plant and animal side of it goes toward the human race. Keeping them fed, keeping mankind fed worldwide, not just nationwide, but worldwide."

\section{Farmers' Social Self-Conscious}

In the theme of farmers' social self-conscious, producers seemed to be very self-conscious when asked about themselves or peers. They did not want to come off as arrogant, derogatory, or be seen as gossiping. A supporting category of this theme was perceived vilification. Producers were certain they were considered "the bad guy" by media, consumers, and other producers.

When speaking about peers, Susie, a mainstream producer, said, "It's not like they're doing it wrong. There's just always room for improvement. There's room for improvement in what we do. I'll be the first to admit that we could improve." Producers were aware when they were the subject of gossip and did not appreciate it. Esther mentioned that when they transitioned from mainstream to niche production the perception of their neighbors was difficult to deal with:

We knew that we were the primary subject at the co-op coffee every morning. The first few years, that was, that was very concerning. We could see one of them drive by just to see what we were doing. They went to the co-op and reported it. There was a lot of poking fun.

Bill, a mainstream producer, felt similarly, "I'm always out here doing experimental things. My neighbors think I'm absolutely crazy."

Perceived Vilification. Mainstream producers were convinced that media and other sectors of agriculture portrayed them as the "bad guy." Wayne, a mainstream producer, stated, "I had no idea that we would become the enemy," when reflecting back on his career and the changing public perception. Lionel, a mainstream producer, spoke about the backlash he has endured on social media: "I post something on Facebook, and someone will be like, 'Oh, you're a farmer so you're just trying to kill us with the chemicals." 'Susie, a mainstream producer, stated, "They think that we're poisoning them with methane emissions," when asked about the public's perception of agriculture.

\section{RQ 2: How do Producers Define a “Good Farmer"?}

In order to understand how producers defined a "good farmer," producers were asked about how they determined if their operation was successful and the factors that contributed to success on agricultural operations overall. The major themes associated with success were innovation and efficiency drives success, farm succession defines success, passion and joy measure success, and profits are paramount for success.

\section{Innovation and Efficiency Drives Success}

In the theme innovation and efficiency drives success, producers believed an innovative and efficient operation determined success and represented a good producer. Susie, a mainstream 
producer said "I think of being innovative as being successful. Right now you can't just do anything that grandpa did. That won't make you successful." Bob, a mainstream producer, spoke of efficiency and labor management as a measure for success: "If it takes everything you got, 18 hours a day just to get everything done and you're struggling, I don't think that's successful."

\section{Farm Succession Defines Success}

In the theme farm succession defines success, producers postulated taking care of land for the next generation and maintaining the integrity of the operation for the future were markers of good producers. Dave, a mainstream producer, said, "As long as you make a living and you feel good about what you're doing. I mean, you want to be good stewards of the land because there's another generation coming up." Wayne, a mainstream producer, said, "You have to have profits to reinvest, to build equity, to transition from one generation to the other, instead of just building it up to sell."

\section{Passion and Joy Measure Success}

In the theme passion and joy measure success, producers thought the joy they got from food production was the best determinant of success. Esther, a niche producer said, "We measure success in farming with the joy we get out of it and the opportunity to grow healthy food for people who are interested in healthy food." Bill, a mainstream producer, echoed these sentiments:

You've got to love what you're doing, if you don't, I don't care how much money's behind it. You got to love what you're doing and know it's going to take perseverance .... Y You got to have that mindset before any operation can be successful. If you don't have that mindset, don't start it.

\section{Profits are Paramount for Success}

Finally, in the theme of profits are paramount for success, producers thought success and being a good producer was defined by the profitability of an operation. Greg, a mainstream producer, said, "This is kind of generic, but I would say that if it can be profitable year in and year out, I think you're a win." Lionel, a mainstream producer, simply defined success as, "If you're making money you're successful." Joe, a mainstream producer, spoke of the volatility of markets and taking advantage of the good years: "You've got to hit them years where the cattle market's high and then try to carry over or pay down what you need to but, yet carry that money to the next year." Margaret, a niche producer, noted the idea of economic sustainability: "You need to be ecologically sustainable as well economically sustainable. You have to be able to earn enough money at what you're doing that you can pay the bills. Maybe even more than pay the bills. That'd be nice."

\section{RQ 3: How Do Producers Relate to and Share Information with Others Involved in Agriculture?}

To understand how producers relate to and share information with one another, participants were asked about their relationships with neighbors, information sources, and perceptions of their respective outgroup. Interviews yielded the following themes: positive regard and respect and producers rely on producer networks for information and support. 


\section{Positive Regard and Respect}

The relationships described by participants were mostly positive and respectful. This theme is defined as the esteem which producers held for one another regardless of production choices. This theme traverses four categories of producers' relationships: intentional neighboring, healthy competition, concern for well-being, and promotion of coexistence. Although some producers had negative comments, the prevailing attitude was one of camaraderie and concern for wellbeing regardless of production practices and products.

Intentional Neighboring. Margaret, a niche producer, felt as though her relationships among neighbors was positive and she was intentional in maintaining them:

Maybe people think we're a little weird sometimes. I haven't ever felt like there was any animosity or anything like that. ... One thing that we have tried to do is to be very careful not to bad mouth conventional producers because I think that's pretty nonproductive.

Tammy, a niche operator, spoke of being surrounded by a supportive farming community:

We try to use a lot of the farmers around us, for instance, like our hay, we bring in our hay from one of the big producers. They brought us, a little half round bale for free. They delivered it themselves. They said, "We thought you might be able to use this for one of your pumpkins, that you spray paint to look like pumpkins. We thought this would be a perfect one for that. Can you use it?" And so they kind of have caught onto the idea of wanting to help us. They see that this is more of a visible farm, where theirs aren't so visible.

Susie, a mainstream producer, strove to be a good neighbor to all, regardless of their production practices: "It's a small community. What I do has implications for everybody, and I'm not going to sit there and cause a hiccup for somebody. . . and we do border the organic guy and we're very cognizant of it." Bill, a mainstream producer, echoed the importance of being a respectful neighbor: "You will never find any better people than there is in agriculture. . . But don't talk about your neighbor or you'll have the rest of the community on ya."

Healthy Competition. Overall, producers did not see neighbors or peers as competition. Tammy, a niche producer, said, "We felt like it was a competition until we started visiting with other farms, and then we realized, you know what, it really isn't." Gary, a niche producer, spoke of demand and its effect on the competitive lens, "So when other farmers say, 'Well gosh, don't you think I'm competition?' And I started laughing. I says, 'Buddy, if all of us had a thousand acres each we couldn't supply the state." Producers were more inclined to see their competition as major corporations or other countries. Dave, a mainstream producer, put it this way, "Since we're such a major exporter, we're in competition with the world. I mean that's where we're at."

If producers did see neighbors or other producers as competition, they were not threatened by them. Bill, a mainstream producer, said this of other ranchers, "We compete, but they're not a threat to me because I've got a better product" Mike, a niche producer, said, "Oh, we're not competitors. The market is big enough to where it's the competition. The only competition we have is who can grow the prettiest and the best. So we push each other and that's a healthy competition." 
Concern for Well-Being. Producers often cited feelings of concern for fellow producers. Issues regarding mental health, suicide, and social isolation were mentioned. For instance, Lionel, a mainstream producer, said,

Farmers are tired and worn out. We've had two or three people around us try to start farming full time, they end up going back to their jobs in town. It was just too much for many of them. One of the reasons was not only the physical toll, but the psychological toll. It can be a depressing job.

Mike, a niche producer, echoed these concerns. "Farming is one of the most stressful jobs. There's so many suicides among farmers .... Y You have no control over it. You can invest everything, money, time, everything, and God can still smack you down." Along with the concern regarding other producers, producers were also concerned about the agricultural industry as a whole and rural communities. Margaret, a niche producer, spoke of the problems facing rural communities: "Small towns and rural communities are depleting. I would like to see a change to help repopulate a rural area, rather than people wanting to get out of here and get somewhere better."

Promotion of Co-Existence. Of the 13 participants, 11 explicitly stated that they respected other producers to make their own choices regarding production practices. Esther, a niche producer, said,

I respect what my neighbors do with their operation. Agriculture is so diverse, and people are more so. Whatever part agriculture plays in their life and the way they feel like they need to do it, I respect. And hopefully some of those people who are so opposed to one type of agriculture over another, well, as they get older, like I am, will realize that there's more to it than just their way.

Gary, a niche producer, said this of mainstream producers, "I never criticized them. You know, what would be the point? If that farmer has been doing this for a generation or two and this is how they grow corn, who am I to tell them what to do?" He compared the idea of telling other producers how to farm as attempting to convert their religion: "Why should I interject my belief? Yeah, that' $d$ be as bad as going in and saying, 'Well, I'm a Catholic.' 'Well, wait a minute, I'm a Baptist. You should be Baptist.' It's like leave people alone!' His final thought on the matter was "Hey, as long as it's not illegal, go for it."

Greg, a mainstream producer, said "People that grow organic, that do both, that's great. More power to them. You know, I think of him as a peer. They just found the market where they can make it work." Joe, another mainstream producer, shared the sentiment, "If they can make it go, that's great."

Whereas producers were supportive of others making their own production choices, they were wary of government regulations that limit their ability to produce on their terms. When speaking about different production practices, Wayne, a mainstream producer, mentioned, "I have no problem with it. I encourage that. I just don't want laws to say that's the way you have to do it. I want the market to determine what's grown, not the federal and state government." Bob, a mainstream producer, echoed these sentiments:

You know, more power to them if they want to do that. The consumer will finally wise up 
eventually, I would think. Maybe not. I have no problem with it when it's in the free market, but when it gets into where it's dictating, you tell me I can't use a GMO, telling me that I can't do this or that, then I come out swinging. That's where the rub is.

The majority of producers were respectful and supportive toward fellow producers. However, there was some dissent as some producers were very critical of other producers' methods. Some mainstream and niche producers saw the other group as lazy. When referencing organic production, Susie, a mainstream producer, said "for some reason instead of doing the hard work and figuring out how to market your crop, they just start bashing somebody else. That seems like what they've done." She also referred to organic production as a "scheme." Gary, a niche producer, shared similar sentiments about mainstream producers, "Why use all the pesticides? Because they [conventional producers] are lazy. They have organics you can put on your crops; they have [predatory] pests you can buy, and they're not expensive. And it's better for you, better for the environment."

Mainstream and niche producers alike said organic farming was reverting back 40 to 50 years. Susie, a mainstream producer, stated "I feel like [organic producers are] trying to farm like my great grandpa did ... there's a push for more research into organics. They did that in the 1950s. This is where we've got ourselves. Why are we going back?" Wayne, a mainstream producer, stated that despite social pressures to change to organic, he has no plans to do so: "I've spent my entire lifetime trying to advance. And to me that's regressing back. And I'm not a regressive person. I mean, that's regressing back to the 1920s. And I can't do that." Even though mainstream producers viewed this regression as negative, niche producers viewed reverting to old practices as positive. Esther, a niche producer, said, "In some ways we've reverted back to what they were doing before those new things came."

\section{Producers Rely on Producer Networks for Information and Support}

When asked about information sources, producers mentioned other producers as sources. Some networks consisted of close neighbors and some networks were far flung. This theme is defined by the self-selected peer network that producers relied upon and traverses the categories of mentorship and social media

Gary, a niche producer, interacted with people outside of his geographic area: "I talk to people all over the U.S., you know, anybody can call me up. Or come down from another state and look at what we're doing." Mike, a niche producer, spoke about neighboring operations as beneficial cooperators: "I can call any of them up right now. I share equipment with some of my neighbors. We're not competitors. The market is so big that we will never be stepping on each other's toes."

Mentorship. Another prevailing function of producer networks, regardless of geography, was mentorship. Producers both desired to serve as mentors and be mentored by others. Bill, a mainstream producer, works to mentor two younger producers in the cattle business. Speaking of one of them, he said, "I told him I'd help him get started. It is so hard for young people to get started because it's capital intensive. I try to help them get started because it's hard to get young people back." Mike, a niche producer, was mentored when he first started farming: "I was fortunate enough to meet an older gentlemen who was very wise. We started working together and shared implements. As far as a mentor, you couldn't ask for a better guy."

Social Media. Social media was often mentioned when producers talked about how they communicate with one another. Nine of the 13 producers interviewed for this study mentioned 
social media as a way they connect with other producers, as well as the public. Tammy, a niche producer, uses Facebook to reach her customers and advertise the farm, but she also uses Facebook to gain and share industry information with agritourism operators from across the nation:

We have learned a lot on that Facebook page [for agritourism operators]. People are just asking questions or sharing their advice, and people aren't afraid to share their failures. No one is trying to keep trade secrets. People want other farms to be successful too.

Susie, a mainstream producer, spoke about the benefits social media can offer a producer:

Farming can be a pretty lonely occupation. I don't feel like it's as lonely as it used to be, because there is much more social media, but before Facebook, Twitter, and Instagram, you would kind of be on your own for days at a time. But with social media you feel like you may not be so alone. There's community there.

\section{Conclusions, Recommendations, and Implications}

This study sought to understand producers' identities and relationships with other producers and communities. The present study found producers' identities were influenced by their occupation, family, and sense of duty. These components of identity are indicative of enacted identity or the identity that is communicated to the outside world (Hecht, 1993). Findings in this study confirmed the idea that occupational identities of producers are deeply entrenched (Abrams et al., 2013). Producers often defined themselves by their occupation of rancher or farmer within their first few sentences. Furthermore, the connection of family to both farming and identity supports past research (Arnold, 2017). In this study, producers communicated about agriculture, which is a key component of their identity, nearly every day. This is important for anyone working with producers or those who are targeting producers in their communications. Identity is a fundamental component that impacts how people interact with the world around them (Hecht, 1993).

Producers defined good producers by their financial success, efficiency, innovation, and longevity of operations. These characteristics are similar to a productivist identity (McGuire et al., 2012). Similar to Phillip and Gray's (1995) findings, when defining a "good farmer," producers indicated innovation and efficiency as factors as well as operation longevity and consistency from year to year. However, producers also noted financial stability and passion for the work as other factors determining the quality of a farmer. The joy and passion for producers expressed for their work is similar to past findings (Van Dijk et al., 2016) Producers were proud of being involved in agriculture and often spoke of the industry's superiority, societal necessity, and rigor. Each producer's communal or collectively defined identity (Hecht, 1993) was marked by this sense of pride and importance related to their industry. Any efforts to foster coexistence among producers should focus on this communal identity to keep producers focused on their commonalities instead of their differences (Mathias et al., 2017; Said, 2019).

Moreover, producers were concerned with not only being a good producer (Phillips \& Gray, 1995) but also a judicious and kind neighbor. The majority of producers in this study were

very conscious not to speak ill of other producers or criticize their production practices, even if they did not agree with others' production practices. Although most were careful to avoid negative 
statements, one mainstream producer referred to certain niche practices as a "scheme" and some niche producers spoke poorly of the quality of mainstream products. There were also participants from both mainstream and niche groups who referred to the other as lazy. This kind of comparative language is representative of the relational frame of identity. Relational identity is how one defines themselves in comparison to others (Hecht, 1993). By naming other producers as lazy or as running a scheme, producers distinguished themselves as hardworking and honest, but they could be undermining social capital between mainstream and niche producers in their community (Sharp \& Smith, 2003). Any collective efforts to foster relationships and social capital in producer communities, such as USDA's priority of coexistence, should emphasize the need to reduce negative communication, such as calling a different group of producers lazy, because only a few negative interactions can undermine much more numerous positive interactions (Sharp \& Smith, 2003).

Overall, producers spoke of a mutual respect for other producers, regardless of their choices in production practices. Although producers may not want to buy or produce the products produced by the other group, they generally supported others' desires to farm as they saw fit. This support ranged from genuine concern and encouragement of other producers to a more laissez-faire mentality. Although producers said they were supportive of others, each producer group felt aggression from the other side of agriculture. Mainstream producers felt attacked by niche producers as though niche producers were attempting to change mainstream production practices. Niche producers often felt the same way about mainstream producers. Moreover, producers were also extremely conscious of being the subject of gossip, particularly if they were trying something new and different. If the participants in the study are reflective of the larger community of producers, then only a few producers are responsible for the majority of producers believing the other group is exhibiting aggression, which could indicate the collective value of social capital can be undermined by a few individuals (Sharp \& Smith, 2003), but more representative quantitative research would be needed to determine this.

Despite the general support of other practices, as Gray and Gibson (2013) found, producers were obstinate regarding their practices and seemed unlikely to change. This points to the chasm between the two groups mentioned by Beus and Dunlap (1990). Despite efforts by the USDA (2015) to create coexistence, perceptions of relationships remain strained even with the majority of producers viewing the other group in a positive light; they often believed the other group harbored negative perceptions. Although past research indicated a rise in competitive feelings between producers (Rotz, 2017), producers in this study did not consider other producers in the area to be competition in negative way. Not only were producers more likely to express concern for the success of other producers than feeling of competition, but they even welcomed the idea of "friendly competition." Producers in the present study were more concerned with international competition than farmers down the road. Neighbors were a popular source of information for producers. These results indicate the potential for coopetition among producers (Bengtsson \& Kock, 2000), but if producers believe the other side of the agricultural chasm is exhibiting hostility, there will not be the requisite respect and trust needed to foster coopetition (Kraus et al., 2019).

Networks were utilized by producers to learn new information, share resources, and even mentor younger producers. Social media played a substantial role in these producer networks. Previous research regarding producers using others as information sources was conflicting. Past studies indicated niche producers were more likely than mainstream producers to use peers for information (Crawford, et al., 2015). Crawford et al. (2015) also indicated online media was an 
ineffective source of information for producers, though it is possible producers have gotten more comfortable with social media in the past few years.

Past research indicated producers were becoming hesitant to turn to neighbors for answers and help (Bell et al., 2004; Rotz, 2017). A different study, found producers shared information related to agriculture regularly (Gray \& Gibson, 2013). While there may not be universal use of networks for information, organizations that seek to improve the agricultural community should foster networks among producers. If producers are hesitant to turn to neighbors for help, social media could provide an opportunity to connect producers across the country and the world. This could be particularly advantageous for producers who are outliers in their local communities.

Results from the present study indicate producers relied heavily upon their neighbors and peers for information. Producer information networks were important for both mainstream and niche producers. Similar to past research, many producers spoke of talking to people every day about agriculture (Gray \& Gibson, 2013). These connections are valuable because they boost social capital, which increases the likelihood producers will trust and support each other (Cole, 2010; Sharp \& Smith, 2003). The mentoring relationships identified in this study align with Cole and Donovan's study that found older farmers are influential and play an important role in building social capital (2008).

In this study producers were concerned about the wellbeing of their peers. Many were concerned about the stress and uncertainty related with working in agriculture, which is similar to past research that described farmers as pessimistic, fretful, and lacking control over their life (James \& Hendrickson, 2010). Producers in the present study described farming as a lonely occupation. This is concerning as a lack of social ties is related to increased risk of suicide (Singh \& Siahpush, 2002), and agriculture has a higher rates of suicide as compared to other occupations (Milner et al., 2013; Tiesman et al., 2015). Producers in the present study were aware of this risk and worried for the health of their peers.

The first set of recommended future research focuses on the generalizability of the results. A quantitative survey of producers in Oklahoma is needed to understand if the results of the present study apply to the rest of the state. To understand the rest of the country, this study should be replicated in other states. Geography and political ideology could affect farmer identity and perceptions of other producers.

The next set of recommended future research focuses on the social networks of producers. While social network analysis of producers dates back several decades, social media sites allow producers the opportunity to interact with producers across the world. A social network analysis of social media connections would be advantageous to see how producers influence each other beyond geographic constraints. Social media sites also allow producers to connect with consumers directly. Social network analysis should assess how producers are connected to consumers. This research should also look at how producers' portrayals of their identities and other producers' identities impact the consumers they are connecting with.

The final set of recommended research focuses on understanding how coexistence between traditional and niche producers can be fostered. Positive connections between traditional and niche producers need to be identified and studied to identify paths for success. Because USDA identified coexistence between producers as a need, those efforts need to be evaluated for their effects. There are webpages and fact sheets available, but first it needs to be understood how many people have viewed those materials, and then the effectiveness of those materials with the target audiences needs to be assessed. 


\section{References}

Abrams, J., Bliss, J., \& Gosnell, H. (2013). Reflexive gentrification of working lands in the American West: Contesting the 'middle landscape'. Journal of Rural and Community Development, 8(3), 144-158. https://www.jrcd.ca

Arnold, P. T. (2017). Identities and persistence of family farm operators (Publication Number 3305) [Master's thesis, East Tennessee State University]. Rural Sociology Commons.

Bell, M. M., Jarnagin, S., Peter, G., \& Bauer, D. (2004). Farming for us all: Practical agriculture and the cultivation of sustainability. The Pennsylvania State University Press.

Bengtsson, M., \& Kock, S. (2000). "Coopetition" in Business Networks - to Cooperate and Compete Simultaneously. Industrial Marketing Management, 29(5), 411-426. https://doi.org/10.1016/s0019-8501(99)00067-x

Bennett, J. W. (1968). Reciprocal economic exchanges among North American agricultural operators. Southwestern Journal of Anthropology, 24, 276-309. https://www.jstor.org/journal/soutjanth

Beus, C. E., \& Dunlap, R. E. (1990). Conventional versus alternative agriculture: The paradigmatic roots of the debate. Rural Sociology, 55(4), 550-616. https://doi.org/10.1111/j.1549-0831.1990.tb00699.x

Bollman, R. D., Reimer, W. (2009) Demographics, employment, income, and networks: differential characteristics of rural populations. Journal of Agromedicine, 14(2), 132-141. https://doi.org/10.1080/10599240902845120

Burton, R. J., \& Wilson, G. A. (2006). Injecting social psychology theory into conceptualisations of agricultural agency: towards a post-productivist farmer self-identity? Journal of Rural Studies, 22(1), 95-115. https://doi.org/10.1016/j.jrurstud.2005.07.004

Brandth, B., \& Haugen, M. S. (2011). Farm diversification into tourism - Implications for social identity? Journal of Rural Studies, 27(1), 35-44. https://doi.org/10.1016/j.jrurstud.2010.09.002

Cole, H. P. (2010). Is there an agrarian imperative? Journal of Agromedicine, 15(2), 76-86. https://doi.org/10.1080/10599241003648207

Cole, H. P., \& Donovan, T. A. (2008). Older farmers' prevalence, capital, age-related limitations, and adaptations. Journal of Agromedicine, 13(2), 81-94. https://doi.org/10.1080/10599240802125680

Crawford, C., Grossman, J., Warren, S. T., \& Cubbage, F. (2015). Grower communication networks: Information sources for organic farmers. Journal of Extension, 53(3). https://joe.org/

Creswell, J. W. (2012). Educational research: Planning, conducting, and evaluating quantitative and qualitative research, $4^{\text {th }} \mathrm{ed}$. Pearson Education, Inc.

DeSantis, L., \& Ugarriza, D. N. (2000). The concept of theme as used in qualitative nursing research. Western Journal of Nursing Research, 22(3), 351-372. https://doi.org/10.1177/019394590002200308

Flick, U. (2009). An introduction to qualitative research. SAGE Publications Inc.

Glaser, B. G. (1965). The constant comparative method of qualitative analysis. Social Problems, 12(4). https://doi.org/10.2307/798843

Gray, B. J., \& Gibson, J. W. (2013). Actor-Networks, Farmer Decisions, and Identity. Culture, Agriculture, Food and Environment, 35(2), 82-101. https://doi.org/10.1111/cuag.12013 
Groth, T.M., \& Curtis, A. (2017). Mapping farmer identity. Why, how, and what does it tell us? Australian Geographer, 48(3), 365-383. https://doi.org/10.1080/00049182.2016.1265881

Hecht, M. L. (1993). A research odyssey: Towards the development of a Communication Theory of Identity. Communication Monographs, 60, 76-82.

https://doi.org/10.1080/03637759309376297

Hyland, J. J., Jones, D. L., Parkhill, K. A., Barnes, A. P., \& Williams, A. P. (2016). Farmers' perceptions of climate change: identifying types. Agriculture and Human Values, 33(2), 323-339. https://doi.org/10.1007/s10460-015-9608

James, H. S., \& Hendrickson, M. K. (2010). Are farmers of the middle distinctively "good stewards"? Evidence from the Missouri Farm Poll, 2006. Journal of Agricultural and Environmental Ethics, 23(6), 571-590. https://doi.org/10.1007/s10806-009-9228-8

Jung E., \& Hecht, M. L. (2004). Elaborating the communication theory of identity: Identity gaps and communication outcomes. Communication Quarterly, 42(3). https://doi.org/10.1080/01463370409370197

Kinchy, A. (2012). Seeds, science, and struggle. The MIT Press.

King, C. A. (2008). Community resilience and contemporary agri-ecological systems: Reconnecting people and food, and people with people. Systems Research and Behavioral Science, 25, 111-124. https://doi.org/10.1002/sres.854

Kraus, S., Klimas, P., Gast, J., \& Stephan, T. (2019). Sleeping with competitors. International Journal Of Entrepreneurial Behavior \& Research, 25(1), 50-66. https://doi.org/10.1108/ijebr-09-2017-0356

Läpple, D. (2013). Comparing attitudes and characteristics of organic, former organic and conventional farmers: Evidence from Ireland. Renewable Agriculture and Food Systems, 28(4), 329-337. https://doi.org/10.1017/S1742170512000294

Lequin, S., Grolleau, G., \& Mzoughi, N. (2019). Harnessing the power of identity to encourage farmers to protect the environment. Environmental Science \& Policy, 93, 112-117. https://doi.org/10.1016/j.envsci.2018.12.022

Mathias, B., Huyghe, A., Frid, C., \& Galloway, T. (2017). An identity perspective on coopetition in the craft beer industry. Strategic Management Journal, 39(12), 3086-3115. https://doi.org/10.1002/smj.2734

McGuire, J., Morton, L. W., \& Cast, A. D. (2012). Reconstructing the good farmer identity: Shifts in farmer identities and farm management practices to improve water quality. Agriculture and Human Values, 30(1), 57-69. https://doi.org/10.1007/s10460-012-9381-y

Milner, A., Spittal, M. J., Pirkis, J., \& LaMontagne, A. D. (2013). Suicide by occupation: Systematic review and meta-analysis. British Journal of Psychiatry, 203(6), 409-416. https://doi.org/10.1192/bjp.bp.113.128405

Phillips, E., \& Gray, I., (1995). Farming 'practice' as temporally and spatially situated intersections of biography, culture and social structure. Australian Geographer, 26(2), 127-132. https://doi.org/10.1080/00049189508703141

Rosin, C. (2013). Food security and the justification of productivism in New Zealand. Journal of Rural Studies, 29, 50-58. https://doi.org/10.1016/j.jrurstud.2012.01.015

Rotz, S. (2017). Drawing lines in the cornfield: An analysis of discourse and identity relations across agri-food networks. Agriculture and Human Values, 35(2), 441-456. https://doi.org/10.1007/s10460-017-9838-0 
Said, Z. (2019). Craft Beer and the Rising Tide Effect: An Empirical Study of Sharing and Collaboration among Seattle's Craft Breweries. Lewis \& Clark Law Review, 355(23). https://law.lclark.edu/law_reviews/lewis_and_clark_law_review/

Sharp, J. S., \& Smith, M. B. (2003). Social capital and farming at the rural-urban interface: The importance of nonfarmer and farmer relations. Agricultural Systems, 76, 913-927. https://doi.org/10.1016/S0883-2927(02)00083-5

Singh, G. K., \& Siahpush, M. (2002). Increasing rural-urban gradients in US suicide mortality, 1970-1997. American Journal of Public Health, 92(7), 1161-1167. https://doi.org/10.2105/AJPH.92.7.1161

Stock, P. V., \& Forney, J. (2014). Farmer autonomy and the farming self. Journal of Rural Studies, 36, 160-171. https://doi.org/10.1016/j.jrurstud.2014.07.004

Stryker, S., \& Burke, P. J. (2000). The past, present, and future of an identity theory. Social Psychology Quarterly, 63(4), 284-297. https://doi.org/10.2307/2695840

Sulemana, I., \& James, H. S. (2014). Farmer identity, ethical attitudes and environmental practices. Ecological Economics, 98, 49-61. https://doi.org/10.1016/j.ecolecon.2013.12.011

Tal, A. (2018). Making conventional agriculture environmentally friendly: Moving beyond the glorification of organic agriculture and the demonization of conventional agriculture. Sustainability, 10(4). https://doi.org/10.3390/su10041078

Tiesman, H. M., Konda, S., Harley, D., Menéndez, C. C., Ridenour, M., \& Hendricks, S. (2015). Suicide in U.S. workplaces, 2003-2010: A comparison with non-workplace suicides. American Journal of Preventative Medicine, 48(6), 674-682. https://doi.org/10.1016/j.amepre.2014.12.011

United States Department of Agriculture. (2015). USDA coexistence fact sheets: Overview. https://www.usda.gov/sites/default/files/documents/coexistence-best-practicesfactsheet.pdf

van Dijk, W. F. A., Lokhorst, A. M., Berendse, F., \& de Snoo, G. R. (2016). Factors underlying farmers' intentions to perform unsubsidised agri-environmental measures. Land Use Policy, 59, 207-216. https://doi.org/10.1016/j.landusepol.2016.09.003

Vesala, H. T., \& Vesala, K. M. (2010). Entrepreneurs and producers: Identities of Finnish farmers in 2001 and 2006. Journal of Rural Studies, 26(1), 21-30. https://doi.org/10.1016/j.jrurstud.2009.06.001

Warren, C. R., Burton, R., Buchanan, O., \& Birnie, R. V. (2016). Limited adoption of short rotation coppice: The role of farmers' socio-cultural identity in influencing practice. Journal of Rural Studies, 45, 175-183. https://doi.org/10.1016/j.jrurstud.2016.03.017 